\title{
Dialogiczność jako warunek konstytuowania się podmiotu. Refleksje wokół Sporu o podmiotowość
}

\author{
Alicja Skrzypczak \\ (Adam Mickiewicz University in Poznań, skalicja@gmail.com)
}

\section{Wprowadzenie}

Pojęcie podmiotowości w tradycji fenomenologicznej nie doczekało się dotąd jednoznacznej, a tym bardziej ostatecznej definicji. Jego zakres jest płynny ze względu na narrację przyjmowaną między innymi w obliczu konieczności rozstrzygania konkretnych dylematów etycznych. Inną przyczyną braku jednomyślności co do warunków konstytuujących podmiotowość jest potrzeba usytuowania proponowanych definicji w określonej dyscyplinie (dyscyplinach): psychologii, kognitywistyce, filozofii umysłu, biologii. Coraz powszechniejsza obecnie perspektywa interdyscyplinarna wydaje się być najbardziej adekwatna i obiecująca, jeśli chodzi o usystematyzowanie owych tych warunków; jest ona niejako wymuszona oczekiwaniami co do nowego modelu podmiotu. Model ten miałby uwzględniać nie tylko osobowość, ale także usprawnienia, rozszerzenia i modyfikacje wykraczające poza jej pierwotne, biologiczne uposażenie. Owe usprawnienia i rozszerzenia dotyczą też procesów i zdolności natury kognitywno-afektywnej w ramach tzw. neuro-i psychoenhancement.

Celem niniejszego artykułu jest analiza warunków konstytuowania się podmiotowości oraz zdefiniowanie relacji między podmiotowością a zjawiskami należącymi do sfery świadomości i tożsamości. Dodatkową, semantyczno-semiotyczną inspirację analiza ta zawdzięcza niekonsekwencji w stosowaniu trzech wymienionych właśnie pojęć (podmiotowość, świadomość, tożsamość) w sposób synonimiczny albo sugerujący wzajemne, przyczynowoskutkowe relacje między ich rzeczywistymi odpowiednikami lub też korelacje innej natury, niezwiązanej z zasadą przyczynowości. Wieloznaczność pojęć takich, jak „podmiot” i „podmiotowość” wymaga zatem systematyzacji warunków i kryteriów, które umożliwią oczekiwaną redefinicję. Jest ona potrzebna z jednego jeszcze powodu: otóż kategoria podmiotowości coraz częściej obejmuje byty humanoidalne lub podmiotowo rozszerzone $\mathrm{w}$ taki sposób, który zakłada nie tylko korzystanie z własnych zasobów poznawczych, operacyjnych, emocjonalnych itd, lecz obejmuje też doskonalenie i wzmacnianie tych zasobów z pomocą substancji bioaktywnych, urządzeń biomedycznych i szeroko rozumianych technologii. Podmiotowość, z którą wiązały się dotąd silnie kategorie intencjonalności, odpowiedzialności i refleksyjności w zakresie normatywnym, konsekwencjalistycznym itd. wymaga 
wręcz pilnej redefinicji, skoro jej zakres znaczeniowy ulega nawet nie tyle ewolucji, ile rewolucji. Gdzieś $\mathrm{w}$ horyzoncie tej redefinicji pojawia się też pytanie o wyjątkowość osoby zdolnej rozpoznać i ocenić własne możliwości podług potencjału, jakim dysponuje: samoświadomość i samoocena stanowią integralne elementy podmiotowości i jej definicji.

Najważniejszą zależnością $\mathrm{w}$ trójczłonowej relacji między świadomością, podmiotowością i tożsamością wydaje się ta, która łączy dwa pierwsze zjawiska. Ich wzajemne warunkowanie się jest fundamentem ukształtowania się podmiotu jako kategorii prawnej, dopuszczania sytuacji odmowy podtrzymywania przywilejów podmiotu na podstawie utraty zdolności świadomego odbierania spostrzeżeń. Zaistnienie podmiotowości bazującej na wykształceniu się świadomości stanowi z kolei fundament dla ustanowienia dialogiczności warunkiem podtrzymywania świadomej podmiotowości w warunkach bezpieczeństwa ontologicznego. Filozofia podmiotu ukierunkowana jest obecnie na osiąganie samowiedzy na drodze dialogu. Popularność zyskuje przekonanie o konieczności tworzenia odniesień i samooodniesień w procesie konstruowania tożsamości będącej produktem świadomego przeżywania własnej podmiotowości. Niniejsza praca wykazuje trudności perspektywy analitycznej we współczesnej refleksji nad podmiotowością, a także zwraca uwagę na konieczność analizowania trzech pojęć we wzajemnej relacji.

\section{Podmiotowość a świadomość}

Mówiąc o podmiocie, uwzględniając to pojęcie także jako kategorię prawną, wskazującą na uzależnienie od władzy zewnętrznej, myśli się o nim jako o „ja” myślącym (Drwięga 2016, 22). Gdy nie rozpatrujemy pojęcia podmiotowości jako opisującego stan prawny osoby, możemy zwrócić się swobodniej ku idei podmiotowości jako cechy immanentnej. Niemniej, narzucona integralność człowieka i jego podmiotowości może wskazywać na możliwość istnienia podmiotowości jako cechy nieuświadomionej. Należy zatem zadać pytanie: w jakim stopniu świadomość legitymizuje kategorię podmiotowości? Marek Drwięga wskazuje, że podmiotowość już sama w sobie stanowi pewien wymiar świadomości. Są to zatem zjawiska istniejące równolegle. Niemniej, pomimo skłonności do nadawania statusu każdemu człowiekowi, wydaje się konieczne, by cecha ta została uświadomiona, by została rozpoznana także przez sam podmiot, którego status pozostaje dotąd nadany, a nie zadany. Drwięga wskazuje na nieodzowność doświadczenia podmiotowości w kontekście doświadczenia afektywnego (2016, s. 30). Zatem podmiotowość warunkowana jest $\mathrm{w}$ takiej perspektywie rozpoznaniem, nazwaniem i uzasadnieniem własnych emocji względem siebie samego.

Świadomość, która konstytuuje osiąganie samowiedzy, a tym samym zinternalizowanie idei podmiotowości, nie dotyczy jednak wyłącznie przeżyć na temat własnej osoby, ale przede wszystkim istnienia zewnętrznych 
uwarunkowań doświadczenia, obiektów i zjawisk, których obecność wyznacza granice i kierunek doświadczenia, intensywność przeżyć angażujących dostępne zdolności afektywne podmiotu jak i indywidualne zdolności kognitywne. Uruchomienie tych zdolności stanowi świadectwo pierwszego warunku świadomości - intencjonalności. Intencjonalność jest immanentną cechą myśli, która towarzyszy rozpoznaniu i definiowaniu stanu psychicznego, usytuowania podmiotu w kontekście środowiskowym. Pojawienie się myśli równoznaczne jest zatem $\mathrm{z}$ ujawnieniem intencji, a więc pewnej formy samoświadomości, dotyczącej sposobów realizowania indywidualnych potrzeb. Te z kolei stanowią o aktach mowy jako warunkowanych przez świadomość. Same akty mowy, jak pisze Robert Piłat, nie są warunkiem wystarczającym do wytworzenia się podmiotowości (Piłat 2016, s. 42). Należy jednak zauważyć, że wraz $\mathrm{z}$ tworzeniem narracji, będącej pewnym układem uzasadnień dla własnych intencji, podmiotowość może się wytworzyć.

Świadomość może być rozpatrywana nie tylko jako czynnik konstytuujący podmiotowość (Novotný 2016, s, 79), ale jako narzędzie, za pośrednictwem którego podmiotowość zostaje zdefiniowana. Konstytutywny dla podmiotowości może okazać się świat zewnętrzny, otoczenie potencjalnego podmiotu, które zawsze doprowadza do ujęcia podmiotowości jako relacji opartej na dialogiczności. Natomiast świadomość może jawić się jako stabilizator zmian (Kozak 2016, s. 92), moment balansowania rejestrowanych różnic pomiędzy światem zewnętrznym, a podmiotem odkrywającym samego siebie i swoje położenie w tym świecie. Świadomość stanowi zatem warunek ustanowienia zharmonizowanej relacji i podtrzymywania kontroli nad zależnością afektywno-kognitywną. Tezę tę potwierdza Andrzej Dąbrowski, który wskazuje na istotę osiągania poziomu samoświadomości jako szczególnej formy świadomości, umożliwiającej rozpoznanie i odpowiedź na pytanie „jak to jest znajdować się w określonym stanie mentalnym?" (Poczobut 2016, s. 124). Jest to zatem okazja do osadzenie doświadczenia samoświadomości w perspektywie analitycznej i refleksji komparatystycznej.

Jednocześnie samoświadomość zdradza możliwość zakwalifikowania jej jako świadomości moralnej, która uwarunkowana jest racjonalnie uzasadnionym rozpoznaniem środków dostępnych dla zainicjowania procesów decyzyjnych, $\mathrm{z}$ uwzględnieniem języka jako narzędzia umożliwiającego to uzasadnienie. Sama zdolność decyzyjności nie jest jednak równoznaczna z założeniem o osiągnięciu celu. Pozostaje on w sferze utopijnych refleksji o realizacji idei moralnych. Stanowi jednak czynnik motywujący do pogłębiania samowiedzy przy jednoczesnym podtrzymywaniu przekonania o własnej niedoskonałości. Zdolność do podejmowania decyzji wskazuje na możliwość zdefiniowania podmiotu jako autonomicznego i posiadającego kompetencję tworzenia samoodniesień. Obie te cechy kreowane są poprzez wypracowania indywidualnej formy bezpieczeństwa ontologicznego bazującego na pewnej rutynizacji działań. Rutyna nie oznacza tutaj jednak postawienia stałej granicy 
pomiędzy tym co znane i zautomatyzowane. Jej rola polega raczej na zbudowaniu wewnętrznej pewności możliwych konsekwencji pewnych wydarzeń, przy jednoczesnym otwarciu się na nowe doświadczenia, które włączone zostają w model podmiotowości. Bezpieczeństwo ontologiczne nie oznacza zatem zahamowania rozwoju samowiedzy $\mathrm{w}$ stadium, które gwarantuje samowystarczalność podmiotu, ale - wręcz przeciwnie - prowadzi do uelastycznienia schematów poznawczych i rozwijania motywacji do spostrzegania wieloperspektywicznego. Może ono zachodzić w sytuacji stabilizacji podstawowych wartości podmiotu, na podstawie których dokonuje on selekcji nowych doświadczeń jako wartościowych i włączanych do procesu samopoznania lub odrzuconych jako nieprzystających do obrazu własnego „ja”.

Podmiotowość może zatem funkcjonować jako kategoria obiektywna. Zostaje ona jednak niezmiennie poddawana subiektywizacji, a jej realizacja odbywa się w ramach perspektywy hermeneutycznej, w której człowiek stawia przed sobą zadania odkrywania istoty własnej egzystencji w interpretacji uwzględniającej kontekst tej egzystencji. Perspektywa hermeneutyczna jest warunkiem ujawnienia się perspektywy dialogu utrwalającej podmiotowość jako cechę podzielaną przez wszystkie osoby, uczestników sytuacji etycznej, których dążeniem jest samointerpretacja (Piłat 2016, s. 39). Ujmowanie podmiotowości wyłącznie jako kategorii obiektywnej kończyłoby możliwość analizowania realizacji tego zjawiska, pozostając na poziomie refleksji czysto analitycznej.

Wydaje się zasadne, by skierować refleksję w stronę rozważań tożsamości jako świadomości. Nie jest to jednak równoznaczne z tym, że świadomość funkcjonuje jako synonim tożsamości. Niemniej, podtrzymuje ona postulat nierozłączności trzech elementów - podmiotowości, świadomość i i tożsamości jako warunkujących się wzajemnie w kreowaniu produktów ich własnych wzajemnych relacji, z których tożsamość samą w sobie można uważać za ten najbardziej złożony, choć nie ostateczny. Świadomość stanowi natomiast w tej zależności podstawę uformowania się kategorii jak i poczucia podmiotowości, które wiąże się $\mathrm{z}$ odczuwaniem własnej osoby jako przynależącej i funkcjonującej $\mathrm{w}$ danym miejscu i czasie (Wierzchoń et al. 2016, s. 148). Podejście takie eliminuje kategorię podmiotowości jako narzuconą, ponieważ wobec takiej perspektywy trudnością byłoby mówienie o możliwości wyewoluowania $\mathrm{z}$ niej tożsamości opartej na autonarracji. Refleksja zostałaby bowiem zredukowana do poziomu anamnezy ograniczonej świadomości polegającej na odtwarzaniu podanej interpretacji raczej niż jej krytycznej interpretacji. Inną konsekwencją ujmowania podmiotowości wyłącznie jako kategorii narzuconej byłoby ryzyko uprzedmiotowienia osoby, pomimo jej statusu określanego jako „podmiot”. Podmiotowość w takich okolicznościach staje się raczej kategorią ułatwiającą określenie przymiotów osoby $\mathrm{w}$ kontekście prawnym, moralnym lub społecznym. Upodmiotowienie natomiast zostaje urzeczywistnione dopiero $\mathrm{w}$ 
procesie autoidentyfikacji (Piłat 2016, s. 38), zdobywania umiejętności opisania samego siebie i swojej roli w kontekście społecznym. Ostatecznie więc podmiot jawi nam się zarówno jako podmiot poznający i przedmiot poznania (Wierzchoń et al. 2016, s. 145). Klasyfikacja ta wydaje się być niepodważalna ze względu na konieczność ujmowania podmiotu zawsze jako części całości rozpoznawanej przez samą siebie jak i przez inne podmioty. Podmiot nie istnieje bez bycia wrzuconym w kontekst, a zatem należy założyć wzajemne oddziaływanie tych dwóch sfer, uwzględniające intencjonalne działania podmiotów sytuacji etycznej. Jednym z takich działań intencjonalnych jest już zdobywanie samowiedzy, dzięki któremu relacja podmiotu do otoczenia zostaje podtrzymana i reinterpretowana.

Podmiotowi oprócz wymiaru moralnego można także, a być może najpierw, przypisać własność podmiotu przeżywającego. Autoreferencyjna refleksja podmiotu odnosi się $\mathrm{z}$ reguły do jego cielesno-kognitywnoemocjonalnej jedności. Niemniej, jak zauważa Patočka, to ciało samo może zostać uznane za pierwszy podmiot, jeszcze przed nadaniem podmiotu jego statusu na podstawie autorefleksji. Ciało nie jest rozumiane jako własność, przedmiot lub nośnik. Jest żywym tworem wyzwalającym energię dla podejmowania działania, dla urzeczywistniania sprawczości podmiotu. Ujawnia zatem swoje znaczenie zanim jeszcze zostanie ono uzupełnione przez sferę refleksji i emocji. Ruch, który charakteryzuje ciało przeżywane, stanowi realizację podmiotowo specyficznego sposobu bycia (Novotný 2016, s. 83; por. także Patočka 2011). Ciało fizyczne i ciało przeżywane stanowią kompilację własności uruchamiających sprawczość podmiotu intelektualną i manualną. Te dwa aspekty prezentują dwa sposoby reprezentacji podmiotowości, odpowiednio: jako kategorii nadanej oraz jako własności samodzielnie odkrywanej.

To jednak nie sprawczość rozstrzyga o możliwości podtrzymania statusu podmiotu, ale świadomość możliwości wykorzystania tej zdolności w dążeniu do obranego celu. Intencjonalność ponownie okazuje się być domeną człowieka w przeciwieństwie do działania motywowanych instynktem bądź zaprogramowanego algorytmu. Współcześnie problem nadania podmiotowości zwierzętom lub bytom humanoidalnym opiera się przede wszystkim na pytaniu o możliwość przypisania im świadomości i intencjonalnie zaplanowanego działania. Argumentem na rzecz trudności nadawania tej kategorii jest m.in. zagadnienie zaburzeń podmiotowości, które $\mathrm{w}$ neuropsychiatrii noszą synonimiczne określenia zaburzeń osobowości lub tożsamości. Niezależnie od zaklasyfikowania tych zaburzeń jako osobowościowych, tożsamościowych lub podmiotowości, ich istotą jest reprezentowanie warstw, którego pozostają podatne na naruszenie status quo, warstw nieelastycznych w związku z nowymi doświadczeniami, które nie są asymilowane z utrwalonymi już schematami poznawczymi i behawioralnymi. Warto jednak przemyśleć zasadność wymiennego stosowania terminów „podmiotowość, „osobowość” i 
„tożsamość” i zauważyć, że podmiotowość jest zaledwie i aż tym, co czyni dopiero fundament struktury osobowości (Wierzchoń et al. 2016, s. 146). Rozpoznana osobowość i związana z nią rola stają się źródłem motywacji dla wyboru działań pożądanych $\mathrm{w}$ danym kontekście, dla wyboru dostępnych możliwości sprawstwa, które nie abstrahują od złożonej struktury emocjonalno-poznawczej.

Wobec powyższych rozważań w obszarze świadomego podejmowania działań przez podmiot, można wysunąć wniosek o przewadze zjawiska doświadczania podmiotowości nad klasyfikowaniem jej jako kategorii przynależnej osobie. Potwierdza to teza Metzingera (Wierzchoń et al. 2016, s. 147) o doznawaniu „ja”, jego subiektywizacji i konieczności wyeliminowania kategorii podmiotowości jako istniejącej obiektywnie. Subiektywizacja ta wiąże się z identyfikacją własnych stanów psychicznych (Wierzchoń et al 2016, s. 147), które osadzone zostają w konkretnym kontekście, zewnętrznych warunkach, wpływających na kondycję psychiczną człowieka. Świadomość jest zatem elementem, który pozwala na zidentyfikowanie tego, na co nakierowane zostają myśl i emocja. To wciąż zbyt mało, by można było mówić o zdobywaniu samowiedzy, jednak rozpoznanie położenia podmiotu jest tym, co osiąganie samowiedzy umożliwia. Samowiedza, jak uzupełnia tę refleksję Hohol, inicjuje koło wzajemnych zależności samowiedzy i stanów mentalnych, dzięki którym możliwe staje się kontrolowanie zdarzeń dostępnych podmiotowości, a także ich antycypowanie przez projekcję na innych umysłach. W takim wypadku należy założyć, że pełnia doświadczenia podmiotowości jest osiągalna za sprawą rozpoznanie jej w innym podmiocie (Hohol 2016, s. 179).

\section{Dialogiczne konstytuowanie się podmiotu}

Ważnym elementem konstytuującym podmiotowość jest sprawczość podmiotu, zdolność do podejmowania samodzielnych decyzji i działania realizowanego na podstawie indywidualnie uzasadnianych podstaw moralności. Cechą podmiotu jest umiejętność odnajdywania motywacji do podejmowania działania i obserwacji zmian dokonywanych poprzez to działanie. Bycie podmiotem wiąże się zatem nierozerwalnie $\mathrm{z}$ zaangażowaniem $\mathrm{w}$ zmianę rzeczywistości lub $\mathrm{w}$ dążność do osiągania zgody co do interpretacji rzeczywistości w komunikacyjno-dialogicznej interakcji z innymi podmiotami.

Podejmowanie uzasadnionych działań jako cecha podmiotu nakazuje zaobserwować inną własność towarzyszącą temu działaniu - zdolność do podejmowania odpowiedzialności za konsekwencje tych działań i za Innego, który zostaje w to działanie zaangażowany przez określonego 'mnie'. Inny jest odbiorcą bądź interlokutorem sytuacji komunikacyjnej, odzwierciedla nasze przywileje jako podmiotów, stanowi dla nas warunek przezwyciężenie samego siebie (Kozak 2016, s. 89). Sytuacja ta staje się nie tyle nieunikniona, co wręcz pożądana, ponieważ bezpieczeństwo ontologiczne, które jest jednym z 
elementów rozpoznania siebie jako podmiotu, nie jest uzyskiwane raz na zawsze. 0 zachowanie bezpieczeństwa ontologicznego podmiot walczy całe życie, zmagając się ze lękiem przez jego utratą, a spotkanie z Innym nie tylko wystawia na próbę, lecz stanowi pretekst do kontroli stabilności własnej tożsamości przy jednoczesnym otworzeniu się na inność. Ustabilizowanie podmiotowości musi zachodzić $\mathrm{w}$ warunkach podtrzymanego, minimalnego bezpieczeństwa ontologicznego, związanego $\mathrm{z}$ rozpoznawaniem własnej tożsamości i cech osobowościowych, mających udział we wchodzeniu w role społeczne. Bezpieczeństwo ontologiczne nie oznacza uległości ani rezygnacji z podjęcia działania. Przeciwnie, podmiot świadomy poczucia własnego bezpieczeństwa wzmacnia swoją autonomię. Zdaje sobie sprawę z faktu, że jego osobową wolność ograniczają zasoby materialne, intelektualne i emocjonalne, jednakże pierwszy rodzaj wolności, który może osiągnąć samodzielnie, wymaga umiejętności zdystansowania się do siebie samego. Wobec tego podmiot sam dla siebie staje się konkurentem i, zależnie od kierunku rozwoju autorefleksji, może nad dominować nad sobą lub poddać się sobie. Poddanie się znacznie ogranicza szanse na rozwój wolności osobistej i oddaje przywództwo Innemu, na którego podmiot narzuca odpowiedzialność identyfikacji. Podmiot rezygnujący z wolności zaczyna afirmować Innego i odkrywać w nim siebie. Tym niemniej, o ile fascynacja Innym i jego podmiotowością nie przeradza się w trwałe porzucenie autorefleksji, ten etap poszukiwania własnego „ja” może skutkować odkrywaniem siebie w Innym, a jednocześnie - przybliżać do idealnej sytuacji etycznej: wzajemnej akceptacji dwóch podmiotów, które rozpoznają siebie jako tego-który-jest-sobą (Ricoeur 2005, s. 277). Postać Innego okazuje się być warunkiem koniecznym dopełniania procesu, jakim jest rozpoznawanie własnej tożsamości. Odzwierciedla relację podmiotu względem otoczenia (Kozak 2016, s. 94) i ujawnia wskazówki na temat możliwych form tej relacji. Pozwala na reżyserowanie przez podmiot, antycypowanie możliwej konstrukcji wydarzeń poprzez obserwację i wzmożoną chęć doświadczania tego, czego doświadcza Inny. Doświadczenie to opiera się jednocześnie na różnicy toż-samości. Podmiot obserwując Innego poddaje refleksji własne możliwości działania w podobnych sytuacjach konstruując własny model reakcji na podstawie rozpoznanych tendencji indywidualnych. Wspierał tę perspektywę Roman Ingarden, uznając podmiot za system izolowany, a jednocześnie - nawiązujący relacje z innymi (Ingarden 1987, s. 194). Ta pozorna sprzeczność polega na wchodzeniu w interakcję z otoczeniem, przed którym podmiot broni się, zanim zinternalizuje jego zasady. U Ingardena ponownie odczytać można zdolność do samosterowności, będącą warunkiem konstytuowania się podmiotu, który swoją autonomię odkrywa poprzez działanie po dokonaniu refleksji opartej na hierarchii wartości przez niego uzasadnianej. Ponownie także można wnioskować o bezpieczeństwie ontologicznym jako konsekwencji zwiększania swojej autonomii w zakresie podejmowania decyzji. Interakcja $\mathrm{z}$ otoczeniem 
jest pierwszym etapem konstruowania dla niego znaczeń. Podmiot jako część całości obcuje ze środowiskiem, które można również ujmować fragmentarycznie. Ostatecznie jednak, poprzez nadanie uzasadnionych znaczeń za pomocą abstrakcyjnych pojęć tworzy narrację. Ta zaś spaja poszczególne elementy środowiska, przedmioty i zjawiska poznawane (Hohol 2016, s. 184). W tej sytuacji sam podmiot powraca do pojmowania samego siebie jako przedmiotu poznawanego. Działa jednak intencjonalnie, uzurpuje sobie zatem prawo do stawiania się $\mathrm{w}$ centrum mikroświata, dopóki nie dochodzi do spotkania z Innym - podmiotem, o którym można założyć, że podobnie postrzega siebie i otoczenie. Podmiot poznający podejmuje odpowiedzialność za nadanie Innemu pewnych cech na podstawie własnych rozpoznanych właściwości umysłu. Taka perspektywa stanowi dowód na niemożliwość ujmowania podmiotowości jako pewnej wstępnej idei (Gallese 2005, s. 106), ale raczej jako skutku interakcji w przestrzeni społecznej. Trudno jednak tym samym rozpatrywać ją jako wytwarzaną.

Dialog, który warunkuje rozpoznanie własnej podmiotowości stanowi motywację dla ustanawiania norm moralnych, podlegających negocjacjom w interakcji z innym podmiotem. Tak prezentuje się relacja pomiędzy tradycyjnie pojętymi podmiotami ludzkimi, obdarzonymi zdolnością dzielenia się refleksją i redefiniowania własnych przekonań w obliczu zmiennych warunków społecznych i cywilizacyjnych. Należy jednak zastanowić się nad odpowiedzią na pytanie jak wyglądać powinno negocjowanie wartości w przypadku nadania statusu podmiotu także bytom zaprogramowanym w sposób sztuczny, odbiegający nawet od genetycznego ulepszania. Przypisujemy humanoidom i robotom cechy ludzkie, osobowościowe i tożsamościowe na podstawie ich zaprogramowanej, zalgorytmizowanej zdolności do planowania, która sama jest pewną konstrukcją norm. Problem zdaje się mieć naturę prawną, a zarazem moralną ze względu na podstawowe pytanie: jak uzgodnić normy dotyczące obu tych obszarów, które miałyby chronić zmieniony podmiot? Aktualna normatywność musi podlegać przemianom np. w tym sensie, że asymiluje zmiany cywilizacyjne. Zachwianie tej normatywności (Łuków 2016, s. 194) budzi sprzeciw w dużej mierze dlatego, że utrudnia rozpoznawanie możliwości bytu, który ulepszono genetycznie lub stworzono mechanicznie, a nie biologicznie. Rozpoznawanie własnej podmiotowości bazuje na porównywaniu z własnym „ja” podmiotu, co do którego zakłada się, że posiada porównywalne możliwości. Poprzez obserwację jego działań redefiniujemy własne. Trudność w ustanowieniu nowych kategorii podmiotu wiąże się także z problemem wzajemnego zaufania w relacji uwzględniającej „nowy” podmiot. Z kolei zaufanie w rozumieniu Anthony'ego Giddensa tworzy podstawę dla poczucia bezpieczeństwa ontologicznego (Giddens 2007, s. 78). Zaufanie wiąże się z przekonaniem, że 'moja' podmiotowość została uznana przez Innego.

Zmiana statusu prawnego i moralnego podmiotu prowokuje do zastanowienia się nad koniecznością przeformułowania koncepcji podmiotu i 
podmiotowości. Treść, zakres, rygor praw i obowiązków podmiotu mogłyby być zależne od tego, jakie zdolności i w jakim wymiarze przejawia podmiot, jakie ma możliwości intelektualne, rozwojowe, emocjonalne, praktyczne itd. Te ostatnie stwarzają najmniej przewidywalny scenariusz, ponieważ w przypadku „ulepszonych” podmiotów mogą obierać dwa kierunki - zdolność do ekspresji emocji może stać uboższa, ustępując miejsca możliwościom intelektualnym, ale może także zostać rozwinięta do poziomu nie mieszczącego się w przewidywanej normie zachowań osoby. W przypadku drugiej możliwości wiązałoby się to z problemem przesunięcia granic np. w diagnostyce chorób psychicznych.

Wobec powyższego, opis nowych form osobowych wymaga najpierw rozpoznania możliwości i ograniczeń „nowych” podmiotów. Niemniej, poznanie ich natury nie jest warunkiem wystarczającym. Punktem odniesienia nadal pozostają podmioty o statusie uwarunkowanym biologicznie. W innym przypadku pojawiłoby się ryzyko dyskryminacji tak uwarunkowanych podmiotów. Z drugiej strony nowym formom potencjalnych podmiotów powinny zostać nadane wartości (np. poprzez upodmiotowienie). Nie mogą one pozostać aksjologicznie neutralne, niezauważone, skoro stworzono je w celu kreowania nowych interakcji.

Ulepszenie funkcji biologicznych, intelektualnych i emocjonalnych ma służyć także podmiotom, które nie zostają poddane się tego typu przemianom. Celem powinna być współpraca, a nie rywalizacja podmiotów ujmowanych tradycyjnie oraz pretendujących do tego statusu. Niemniej, do pewnego stopnia następuje próba antropomorfizacji (Łuków 2016, s. 201), podmiot staje się niedookreślony, poszerzony zostaje zakres kryteriów, które definiowałyby go jako jednostkę obdarzoną zdolnością sprawstwa, stanowiącą o możliwości wykreowania tożsamości opartej na świadomej identyfikacji działań i postaw, które te działania uzasadniają.

\section{Konsekwencje uznania konstytutywnej roli dialogiczności dla podmiotu}

Rozważając dialogiczność jako warunek konstytuowania się podmiotu, warto także pochylić się nad zagadnieniem autonomii, która w tradycyjnym ujęciu podmiotowości ujawnia się poprzez odniesienie do innego podmiotu, oraz problemem odpowiedzialności, którą podmioty podejmują, aby utrwalić wzajemnie swoje statusy. Dylemat polega na tym, że nie sposób ostatecznie rozstrzygnąć o tym, czy mamy do czynienia z podmiotem autonomicznym, jeśli jego podmiotowe funkcje zmodyfikowano lub zaprogramowano (Nowak 2016, s. 210). Z kolei o odpowiedzialności można wówczas mówić jedynie w wyłącznie w kontekście nakładania jej, a nie podejmowania. Nawet, jeśli zdolność do autonomicznego podejmowania decyzji przez byty humanoidalne zostałaby uznana, niewymierna pozostaje kwestia badania poczucia 
odpowiedzialności, które humanoid miałby prezentować. Odpowiedzialność wiąże się bowiem $\mathrm{z}$ kalkulacją możliwych konsekwencji działań przy uruchomieniu kompetencji moralnych, które pozostają na razie w sferze idei futurystycznych. Myślenie deontologiczne czy konsekwencjalistyczne wydaje się być obce i nieprogramowalne. Brak możliwości refleksyjnego podjęcia odpowiedzialności skutkuje niemożliwością późniejszego pociągania do odpowiedzialności nowego podmiotu, a jednak wydaje się równie ważne, by moralna i prawna ochrona została mu nadana.

Kolejnym problemem $\mathrm{w}$ nadawaniu tworom humanoidalnym statusu podmiotu jest problem jego dążenia do przezwyciężania własnego „ja” w autoidentyfikacji, podczas spotkania z Innym. Należałoby tu albo zrezygnować z tezy o konieczności potwierdzania własnej podmiotowości przez konfrontację z podmiotowością Innego, albo uznać osobliwość relacji osoby i bytu humanoidalnego. Odkrywanie podmiotowości zakłada odczuwanie motywacji do wykonania działania, w które Inny będzie zaangażowany. Niewymierna natura tej właściwości skłania do poddania w wątpliwość tego, czy rozszerzanie zakresu kategorii podmiotu jest zasadne.

Dotychczas jednym $\mathrm{z}$ podmiotowych przywilejów było także zdobywanie samowiedzy. Celem tego procesu nie było jednak odkrywanie jakiejś ostatecznej prawdy o sobie, a raczej formowanie charakteru moralnego (Warmbier 2016, s. 228). Jednak samowiedza uwarunkowana uprzednim spotkaniem z Innym jest produktem motywacji działania zmierzającego do świadomego zawieszenia własnego poczucia bezpieczeństwa dla osiągnięcia głębszej samowiedzy. To Inny potęguje dynamikę osobowości podmiotu, prowokuje do refleksji nad możliwościami i granicami ujawniania siebie. Można zatem powiedzieć, że podmiot dysponuje wolną wolą, jednak w swoje działanie moralne włącza także działania utylitarystyczne, bazujące na rachunku potencjalnych zysków i strat ze spotkania z Innym. Działanie moralne podmiotu jest zatem konsekwencją elementów takich jak pragnienia samowiedzy, wzmacnianie poczucia bezpieczeństwa i przynależności, namysł nad środkami, możliwościami i konsekwencjami tych działań i wolna wola.

Z drugiej strony należy odrzucić tezę o całkowitej zależności zdobywania samowiedzy od postawy hermeneutycznej wobec Innego, sprowadzanej do pewnego rodzaju uległości wobec jego interpretacji na temat podmiotu. Podzielając podobne skłonności do prezentowania motywacji i lęków w sytuacji spotkania, dwa podmioty uznają wzajemne poddaństwo, a jednocześnie pełniej uświadamiają sobie władzę nad drugim podmiotem. Niemniej, wzrost poczucia władzy nie jest wprost proporcjonalny do poziomu samowiedzy; nie potęguje więc ryzyka zapomnienia Innego $\mathrm{w}$ jego podmiotowości i dążenia do jego uprzedmiotowienia. 


\section{Podmiotowość a tożsamość. Konkluzja}

Problem podmiotowości generuje z grubsza dwa nurty refleksji: pierwszy z nich wskazuje na podmiotowość jako własność osoby wynikającą z jej praktyk społecznych, która zostaje rozpoznana, a nie nadana. Wówczas takie ujęcie podmiotowości staje się niemalże synonimem pojęcia tożsamości. Wynika to $\mathrm{z}$ założenia o przysługującej podmiotowi autonomii, z której może on korzystać bez uprzedniej walki. Drugi nurt charakteryzuje podmiotowość raczej jako kategorię immanentną, w przeciwieństwie do tożsamości, która ma mieć charakter deskryptywny i może być produktem refleksji stabilizującym miejsce podmiotu w jego otoczeniu i relacjach z tym otoczeniem. Refleksję tę generuje pamięć o doświadczeniach, w które podmiot był aktywnie zaangażowany i/lub które zinternalizował jako narrację.

Współczesne koncepcje podmiotowości nader subtelnie zakreślają granice i wskazują na punkty styczne między podmiotowością i tożsamością. Tym sposobem w najnowszej literaturze odnaleźć można koncepcje podmiotu jako tworu powstałego ze zintegrowanych wielu „ja” (Castañeda 1999, s. 200). Jeżeli natomiast mamy do czynienia $\mathrm{z}$ integracją to odbywa się ona poprzez rozpoznanie, hierarchizację i skompletowanie elementów tożsamości. Wobec czego zachodzi możliwość interpretacji zupełnie przeciwnej od tych forsowanych dotychczas - dopiero wielość tożsamości formuje podmiot.

Niemniej, największą popularność wydają się zyskiwać koncepcje, które uwzględniają kreowanie podmiotowości i tożsamości na podstawie spotkania z Innym. Sama sytuacja komunikacyjna nie jest wystarczająca dla rozpoznania i kształtowania własnej podmiotowości. Aby podmiot mógł określić siebie jako posiadającego tożsamość, konieczne jest, by rozpoznał w sobie zdolności kognitywne i refleksyjne. Szansą na to jest podjęcie odpowiedzialności za Innego (Kozak 2016, s. 97) i zainicjowanie procesu przypisywania mu tożsamości równolegle z procesem określania własnej. Inny pojawiający się w każdej nowej sytuacji jest także czynnikiem weryfikowania tożsamości już zdefiniowanej na podstawie wcześniejszych doświadczeń. Pozwala na rozbudowaną samoidentyfikację, a jednocześnie na umacnianie naczelnych wartości, które konstytuują podmiot spójny zarówno z samym sobą, jak i z otoczeniem. Destabilizacja tożsamości, której przyczynę stanowi spotkanie $\mathrm{z}$ podmiotowością Innego, wytwarza potrzebę podjęcia odpowiedzialności za przywrócenie stabilności „ja”, poszerzonego teraz o nowe doświadczenie, tj. spotkanie z Innym. Raz podjęta odpowiedzialność staje się niezbywalną cechą podmiotu, ponieważ nawet rezygnacja $\mathrm{z}$ podejmowania odpowiedzialności angażuje inne podmioty do tego, by obciążyć go odpowiedzialnością na podstawie ich własnej, równorzędnej potrzeby samoidentyfikacji, a także uruchamia procesy kognitywne celem poznania siebie za pośrednictwem Innego.

Tożsamość może być także interpretowana jako profil osobowościowy (Poczobut 2016, s. 117). Mając na uwadze podstawowe cechy osobowości, takie 
jak zdolność do przyjmowania ról, należy włączyć w refleksję o tożsamości jej postać wieloraką, hybrydową. Jednocześnie nawet tak złożona tożsamość powinna być charakteryzowana przez jedność stanu ciała, umysłu i duchowej sfery podmiotu oraz odniesienie tego stanu do relacji z otoczeniem. Wówczas podmiotowość nie zakłada jeszcze takiej relacji, ale jest warunkiem jej powstania.

Podmiot definiowany poprzez zdobywanie samowiedzy drogą refleksji zdawał sobie sprawę z własnych niedoskonałości (Nowak 2016, s. 220), ograniczeń kognitywnych i emocjonalnych. Metody enhancement i neuroenhancement mają szanse te niedoskonałości tuszować i korygować, a jednocześnie wzbogacać możliwości. Braki nie są uświadamiane, a jedynie identyfikowane i eliminowane $\mathrm{z}$ zewnątrz. Nie zauważamy zatem procesu dochodzenia do racjonalnych wniosków przez sam podmiot. Gotowy algorytm uniemożliwia zaistnienie tożsamości autentycznej i tożsamości moralnej, ponieważ nie ujawnia się proces zdobywania kompetencji moralnych. Wzmocnienie postrzegania i doświadczania afektywnego nie jest wcale gwarantem dokonywania lepszej oceny moralnej ani sposobem na wytworzenie poczucia odpowiedzialności związanej z przeżywaniem emocji, stresu. Tożsamość narracyjna zagubiłaby wówczas swój sens, ponieważ twory posługujące się zasobem pamięci, który zostaje zaprogramowany, nie otrzymują możliwości samodzielnego reflektowania nad elementami własnej tożsamości, które stanowiłyby rdzeń dla tworzenia kombinacji na podstawie posiadanych doświadczeń. Fundament zostaje uprzednio zaprogramowany i nie może być uznany za podstawę aksjologiczną i kognitywną nowego podmiotu. Tożsamość $\mathrm{w}$ odniesieniu do tradycyjnie pojmowanego podmiotu nigdy nie pozostaje moralnie neutralna. Afektywność jest bowiem jednym $\mathrm{z}$ kształtujących ją elementów. Troska o biologiczne podstawy podmiotowości (Łuków 2016, s. 203) wciąż wydaje się silnym czynnikiem blokującym możliwość ukonstytuowania tej kategorii jako prawnej i moralnej dla bytów humanoidalnych. Tym samym bowiem redefinicji wymagałaby tożsamość jako rezultat rozpoznawania indywidualnych możliwości kognitywnych, emocjonalnych i fizycznych. Autoidentyfikacja wydaje się pozostawać jednym z warunków konstytuowania tej tożsamości w sytuacji spotkania z Innym.

\section{Literatura}

Castañeda, H.-N. 1999. "The Self and I-Guises." W: H.-N. Castañeda, The Phenomeno-Logic of the I. Essays on Self-Consciousness. Bloomington: Indiana University Press.

Drwięga, M. 2016. „Spór o podmiot w filozofii.” W: A. Warmbier (red.) Spór o podmiotowość - perspektywa interdyscyplinarna (s. 21-35). Kraków: Księgarnia Akademicka. 
Gallese, V. 2005. „Being Like Me: Self-Other Identity, Mirror Neurons, and Empathy." W: S. Hurley \& N. Chater (red.) Perspectives on Imitation: From Cognitive Neuroscience to Social Science (s. 101-118). Cambridge, MA: MIT Press.

Giddens, A. 2007. Nowoczesność i tożsamość. Tł. A. Szulżycka. Warszawa: PWN.

Hohol, M. 2016. „Ucieleśniony podmiot: od wspólnej rozmaitości do „Ja.” W: A. Warmbier (red.) Spór o podmiotowość - perspektywa interdyscyplinarna (s. 177-190). Kraków: Księgarnia Akademicka.

Ingarden, R. 1987. Spór o istnienie świata, T. II. Warszawa: PWN.

Kozak, M. 2016. „Stawanie się podmiotem jako przezwyciężanie samego siebie w ujęciu Emanuela Levinasa." W: A. Warmbier (red.) Spór o podmiotowość - perspektywa interdyscyplinarna (s. 89-100). Kraków: Księgarnia Akademicka.

Łuków, P. 2016. „Poprawianie natury ludzkiej i nieuchwytny podmiot”. W: A. Warmbier (red.) Spór o podmiotowość - perspektywa interdyscyplinarna (s. 193-205). Kraków: Księgarnia Akademicka.

Novotný, K. 2016. „'Ja pasywne' i 'pojedyncza podmiotowość żywego ciała”. W: A. Warmbier (red.) Spór o podmiotowość - perspektywa interdyscyplinarna (s. 77-88). Kraków: Księgarnia Akademicka.

Nowak, E. 2016. „Jaźń jako pacjent chroniczny”. W: A. Warmbier (red.) Spór o podmiotowość - perspektywa interdyscyplinarna (s. 207-224). Kraków: Księgarnia Akademicka.

Patočka, J. 2011. Aristote, ses devanciers, ses successeurs. Tł. E. Abrams. Paris: Vrin.

Piłat, R. 2016. „Podmiotowość jako relacja osoby do jej własnej przyszłości”. W: A. Warmbier (red.) Spór o podmiotowość - perspektywa interdyscyplinarna (s. 37-59). Kraków: Księgarnia Akademicka.

Poczobut, R. 2016. “Podmiot i cognitive science." W: A. Warmbier (red.) Spór o podmiotowość - perspektywa interdyscyplinarna (s. 115-128). Kraków: Księgarnia Akademicka.

Ricouer, P. 2005. O sobie samym jako innym. Tł. M. Kowalska. Warszawa: PWN.

Warmbier, A. „Rozwój świadomości moralnej i formy doskonalenia motywacji”. W: A. Warmbier (red.) Spór o podmiotowość - perspektywa interdyscyplinarna (s. 225-248). Kraków: Księgarnia Akademicka.

Wierzchoń, M. et al. 2016. „Poznawcze i neuronalne mechanizmy doświadczania podmiotowości”. W: A. Warmbier (red.) Spór o podmiotowość - perspektywa interdyscyplinarna (s. 145-160). Kraków: Księgarnia Akademicka. 
Alicja Skrzypczak

(Adam Mickiewicz University in Poznań, skalicja@gmail.com)

\title{
Dialogical Preconditions of the (Self)Constitution of the Subject. Rethinking Dispute over Subjectivity
}

\begin{abstract}
The aim of the paper is to show the conditions of subjectivity constitution in terms of dialogue and the figure of the Other. The analytical and hermeneutical approach I hold is the foundation of interdisciplinary attempt to describe possible concepts of shared relation of the terms: consciousness, subjectivity and identity. The three appear to be recognized only in the ethical
\end{abstract}


situation. It requires taking responsibility for the Other, for giving him the identity which mirrors one's subjectivity. In this way the subject learns the limits and chances for gaining self-knowledge. The paper also presents a new approach towards redefining the definition of subjectivity, which includes artificially and medically enhanced entities.

Keywords: subjectivity, consciousness, identity, dialogue, self-knowledge, selfconstitution

Ethics in Progress (ISSN 2084-9257). Vol. 7 (2016). No. 1, Art. \#18, pp. 284-298.

doi: 10.14746/eip.2016.1.16 